\title{
Stocks’ pricing dynamics and behavioral finance: A review
}

\author{
Paritosh Chandra Sinha*
}

Assistant Professor in Commerce, RabindraMahavidyalaya, PO - Champadanga, Dist - Hooghly, W.B., India. PIN - 712401

\begin{tabular}{l}
\hline C H R O N I C L E \\
\hline Article history: \\
Received March 25, 2015 \\
Received in revised format June \\
12015 \\
Accepted June 272015 \\
Available online \\
July 12015 \\
\hline Keywords: \\
Stocks' Pricing Dynamics \\
Information Noise \\
Behavioral Finance \\
Literature Review
\end{tabular}
\begin{abstract}
A B S T R A C T
In a brief review of the literature on stocks' pricing, the study shows that information vis-à-vis noise serves critical roles in the equilibrium process. It is dynamic in nature and there are different infiltrating aspects from the standard finance to behavioral finance points of views. The aspects of market efficiency, fundamental risk, noise traders' risk, and implementation costs make the stock markets noisy and thereby, limit the arbitrage opportunity of informed traders. Investors' psychological bases viz., belief and preferences contribute more in the equilibrium process. Beliefs include representativeness, conservativeness, and anchoring, availability biases, optimism and wishful thinking, overconfidence, and herd behavior tendency on the part of the investors. On the preferences, investors are influenced by disposition effect, prospects based on reference points, mental accounting, ambiguity aversion, and self control.The study explores the empirical literature also and reviews the six puzzles in the standard finance. Finally, the work identifies a few research gaps to be addressed in the literature.
\end{abstract}

\section{Introduction}

In Financial Economics, investors' behaviors in relation to stocks' trading and equilibrium price formation in the stock markets are broadly explained by two competitive schools of market microstructure theories viz., Standard Finance and Behavioral Finance. In the former school, investors are rational and stocks' prices impound only relevant information. At presence of interdependent demand and supply of stocks along with their quasi supply of the primary capitals, the stock market is desired to be "efficient" rather than "quasi efficient". The market is described by the quality of new information, its speed of arrival, and possible temporal miss-pricing (Ilinski \& Stepanenko, 2008). In the latter school, investors are not only normal but non-rational and quasi-rational as well; and the stocks' prices impound information (economic) and non-information (non-economic) aspects. Thus in contrast to the efficient market hypothesis, the stock markets are noisy at the dispensations of the joint activity of informed and uninformed long-term vis-à-vis short term traders (De Long et al. 1990; Black, 1986).

* Corresponding author. Tel: +91-9732339694

E-mail address: paritoshchandrasinha@gmail.com (P. C. Sinha) 
On confrontations, stocks' pricing dynamics attract research connotations of noise vis-à-vis information. If new information is costless and relevant in the markets' pricing mechanism, at least theoretically, stocks’ prices follow the Efficient Market Hypothesis, EMH (Fama, 1965; 1970; 1991) or a random-walk of drunken persons. In EMH, none can interpolate or extrapolate ones' time and money by way of discovering profitable arbitrage strategy. At information costs, an "informationally efficient market" turns out to be a null set where traders with homogeneous information never trade financial instruments(Grossman \& Stiglitz, 1980). "Noise” is pseudo-information; investors interpret it as if information; it makes investors' observations imperfect (Black, 1986). The uninformed "noise” traders make trades happen in the markets (Grossman, 1976; Black, 1986). They supply systematic liquidity (Huberman \& Halka, 2001; Black, 1986).Noise traders persistently provide liquidity and survive in the long run (DeLong et al. 1991).Their short-run price impacts are different from long run survivals (Kogan et al. 2006).

In the behavioral finance, "noise” has critical roles in stocks' equilibrium price formation. The price includes economic and non-economic aspects, political and non-political interests, and homogeneous and heterogeneous investors' groups. Economic aspects include informed traders' limits to arbitrage (Shleifer \& Vishny, 1997), systematic noise (Barber et al. 2003), fundamental risk, and noise traders' risks (DeLong et al. 1990; 1991). The non-economic aspects comprise of the traders' behavioral biases, heuristics and framing effects (Shefrin, 2007), emotional vis-à-vis cognitive issues (Shefrin, 2000), and herd behaviors (Devenow \& Welch, 1996), and political interests i.e., power conflicts between lender and borrower. These embraceherd behaviours at agency conflicts and information differentials among investors in the mutual fund investments (Brennan, 1993).There is "a separation of brains and capital" (Shleifer \& Vishny, 1997).

Theoretically, Grossman and Stiglitz (1976, p. 250-251) interject that if an unknown return of a stock $\left(r_{t}\right)$ has two components $\eta_{t}$, the fundamental value (known at cost) and $\varepsilon t$, error term (unknown), then "in the absence of noise, with costly information, an (Nash) equilibrium does not exit, .....when a positive fraction of the population becomes informed the price system is fully informative, so it does not pay anyone to purchase information”. In kyle's (1985) dynamic model with a single risk neutral informed insider, random noise traders, and competitive risk neutral market makers, firstly, the insider and noise traders place their market orders and thereafter, the market makers set a price and trade the quantity to clear the markets. Here, innovations in order flows make prices fluctuate in sequential equilibrium and prices reveal information gradually at an end of trades.

In sharp contrast to Kyle's assumption, noise traders are either homogeneously or heterogeneously distributed rather than randomly distributed. The multi-period auction model with multiple strategic informed traders, in Holden and Subrahmanyam (1992) has shown that "informed traders trade very aggressively" and "even just two informed traders cause nearly all of their common private information to be incorporated into prices almost immediately and cause the depth of the market to become extremely large”. In contrast to kyle (1985) and Holden and Subrahmanyam (1992), noise traders survive persistently (Kogan et al. 2006); and informed insider traders' monopolistic power with arbitrage benefit is limited and the same fades over the consecutive trades (Shleifer \& Vishny, 1997; Ljungqvist \& Qian, 2014).

On the said different facets of noise traders in stocks' pricing dynamics, this paper puts into a critical review of the literature. In developing the rest, Section 2 deals with the theoretical foundation of stocks' equilibrium pricing dynamics, information and noise. Section 3 briefly reviews the empirical studies. Section 4 synthesizes the behavioral implications of the puzzles in the standard finance and Section- $V$ identifies a few current research gaps. Finally, Section 5 concludes the work with comments. 


\section{Theoretical Bases}

Since Kahneman and Tversky $(1979,1974)$, the behavioral finance studies have set forth many confirming evidences that the economic men are very unlikely the real men (Edwards, 1954, p. 382). Their investment behaviors are little explained by the traditional finance paradigms viz., the subjective expected utility theory, the Bayesian learning model, and the rational expectations theorem (Barberis \& Thaler, 2003).The literature suggests that limits to arbitrage, at information costs and traders' psychology, holdthe central algorithms in investment decisions (Thaler \& Barbeis, 2002). The study now reviews these issues.

\subsection{Limits to Arbitrage}

An arbitrage strategy is simultaneous purchase and sale of a product in two different markets for getting profitat its price differentials (Sharpe \& Alexander, 1990). Fama (1965), Sharpe (1964), and Ross (1976) argue that many arbitrators at infinitesimal time positions make arbitrage exist, risk neutral, and helpful in revealing stocks' fundamental values. Such equilibrium depends on costless information flow and effortless judgment as well. Another arbitrage strategy is taking off-setting long and short positions and holding until convergence of prices. Researches show that arbitrage equilibrium in real markets is subject to information costs and effortful market judgment by arbitrageurs as well (DeLong et al. 1990).At presence of the noise traders, arbitrageurs, and investors in arbitrage funds, Shleifer and Vishny (1997) show that arbitrageurs are subject to risk and capital while arbitrage becomes futile if stocks' prices diverge far from fundamental values, where noise traders' equilibrium demand causes underinvestment of funds. The limit to arbitrage is related to the following important risk factors.

\subsubsection{Market Efficiency}

Are our known capital markets efficient? The stocks' price discovery is a dynamic process at continuous flow of information, rumors, and innuendos and the same is confronted among informed arbitrageur and noise traders. Therefore, “...market efficiency is a journey, not a destination....strictly speaking the answer is always no” (Lee, 2001; p. 237). Arbitrageurs and mis-pricing always co-exist in the equilibrium pricing (Lee, 2001). At presence of both informed and noise traders, the equilibrium pricing mechanism tallies the limit order book of investors and thus, stocks' prices deviate from their fundamental values. The presence of "risk-lees profit" instead of an "arbitrage opportunity" becomes the most necessary criterion in proving the null hypothesis of the capital market efficiency (Malkiel, 2003).

\subsubsection{Fundamental Risk}

Fundamental risk refers to the risk due to deviations of stocks' prices from the "true values", which are defended by the connotations of fundamental firm-specific and macroeconomic news. Once buying a stock, informed arbitrageur can hedge fundamental risk through sorting with perfect substitutes. But, stocks are rarely perfectly substitutes. Enhancement in fundamental risk enlarges the neighborhood which noise traders share and it reduces relative returns that may be earned by intelligent informed traders (DeLong, 2005). At much fundamental risk, intelligent investors resist to gamble against noise traders if the latter dominates the market. On the impacts of noise traders on the stocks' prices, Shiller (1984), and Campbell and Kyle (1988) have argued for arbitrageurs' aversion to fundamental risk. They have shown that this aversion can by itself limit arbitrage badly even at arbitrageurs' positioning at infinite horizons. However, fundamental risk includes systematic risk and idiosyncratic risk (Shleifer \& Vishny, 1997; p. 50). Pontiff (2006) shows that arbitrageurs are unable to hedge idiosyncratic risk, which forces them in taking limited positions in mis-priced stocks in the project. 


\subsubsection{Noise Traders’ Risk}

In contrast to Friedman (1953) and Fama (1965) that irrational investors are disappeared from the market eventually by arbitrageurs in the long run, DeLong et al., (1990) have shown that arbitrageurs are risk averse and they take shorter position along with their limited ability to counteract noise traders. If noise traders are optimistic (pessimistic) about stocks' future prices, they drive price up (down) further, and arbitrageurs' short horizon positions result in losses at buying (selling) the stocks. Hence, noise traders create their own trading space and arbitrage does not deter noise traders in the markets. This additional risk is borne by short horizon market makers. Kogan, et al.(2006) show that noise traders' risk may not confirm long-run survival but their portfolio policies may diverge from their limits long after the price process meet its long-run limit. DeLong et al. (1991) have confirmed long-run survival of noise traders, who can successfully "invade" the informed population. Bucher and Woehrmann (2006) argue that rational traders target higher cash-inflow from dividends while noise traders indulge speculating on the capital gains. Hence, rational and noise traders do co-exist in the long run.

\subsubsection{Implementation Costs:}

Based on Kyle's (1985) model with single informed trader, large market makers, and groups of noise traders, Foster and Viswanathan (1990) have shown that information advantage declines over time. It is affected by daily public signals. Transaction and holding costs make arbitrage costly (Pontiff, 2006). Arbitrage trading faces transaction costs viz., commissions to brokers, bid-ask spreads and the price impacts of irrational traders (Kogan et al. 2006). These make it less attractive. Since arbitrage needs taking short or long positions, arbitrageur faces short-sale constraints (D'Avolio, 2002; Jones \& Lamont, 2002). Borrowing stocks' fee, legal restrictions for pension fund and mutual fund managers, and costs of searching, finding and learning about mispricing restrict arbitrage trading. Merton (1987) shows that at observed mispricing, arbitrageurs bear exploitation costs. Arbitrage at insider information draws information acquisition costs while such information attracts legal bindings. However, shallowpocketed "arbitrageurs" on innovation through buying the overvalued stocks and selling the same at corrections may sidestep implementation costs (Ljungqvist \& Qian, 2014).

\subsection{Traders' Psychology}

Besides the stated market microstructure algorithms on the stocks' trading, the behavioral finance offers role of psychology in investment decisions. Kahneman and Tversky (1979) have shown that investors in the stock markets violate the Expected Utility Theory of Von-Neumann \& Morgenstern (1944) and Savaga (1954). The systematic biases, which crypt into investors' decision makings, result in weights for the beliefs and preferences in the stocks' equilibrium prices. In the following, the paper reviews how stocks' pricing dynamics, information and noise are related to investors' beliefs and preferences.

\subsubsection{Beliefs}

What would be the score of event "A" tomorrow? "A" may a stock's prices or a bet on the results of a general election or the exchange rate of the Indian rupee in the terms of the US dollar. People form belief on the likelihood of some uncertain future events. Their "belief" is personal expectation derived on a few limited heuristic principles (Kahneman \& Tversky, 1974). Heuristic replaces assigning complex objective probabilities by subjective ones. In predicting future values, it results in systematic errors and judgment biases. 
Representativeness heuristic refers to myopic view of some unknown event (A) by some known event $(B)$ such as $A$ resembles $B$. Representativeness explores little new information and provokes noises in choice formation process and leads to judgment biases. These biases are insensitivity to prior probability of the outcome, insensitivity to the sample size, misconceptions of chance, insensitivity to predictability, illusion of validity, and misconception of regression. Firstly, people impose subjective probabilities on future outcomes against scripted description about an event and they forget his prior probabilities at its absence. Secondly, people assess likelihood of event's sample result by its similarity to corresponding parameters even though population parameters do not depend on sample size. Thirdly, people expect that essential feature of process/ sequence will be represented not only globally but also locally in the parts. Fourthly, people predict stocks' prices upon some descriptive background even if its reliability is not confirmed. Fifthly, people express confidence on a good fit of a system even if they know that itis conditional to the input information. In the misconception of regression, finally, people wrongly perceive regressions to mean "good (bad) trail precedes bad (good) trail" as if "punishment (reward) against some action leads to one's success (failure)”. Shefrin (2007) explains the negative return-risk correlation as representativeness where investors assume stocks of presently "high return and low risk” have good future prospects.

\section{(b) Conservativeness}

Conservatism refers to situations where bases are overweighed relative to sample evidence (Edwards, 1968). People cast more emphasis on their prior probability of outcomes. At possible conflict of cognitive data processing about to put more emphasis, if people find sample being more representative to their known model then they may overweight the data otherwise may show conservativeness to priors. Again, if people perceive that new information or description about stocks' performances as offered by dealers or brokers is coming from not fully reliable source, then people may show conservatism to their priors (Corner et al. 2010). People show belief perseverance and they stick to their priors tightly for long periods (Lord et al. 1979). They vows reluctance to new information that contradicts their beliefs and treat such results, if any, with excessive skepticism (Barberis \& Thaler, 2003).

\section{(c). Anchoring}

Once people base their pricing estimates on some incomplete computation or on a given (and / or arbitrary) asking price, then anchoring occurs. They form estimates at deviation from the said (and / or arbitrary) starting points while such adjustment is insufficient (Kahneman \& Tversky, 1974).Here, they usually overestimate (underestimate) the probability of conjunctive (disjunctive) events and thereby, lead to unwarranted optimism (pessimism) in evaluating any project. The "ask-price" set forth in different business media well before trading day or session may serve as an anchor or heuristic (Bokhari \& Geltner, 2010). Such anchors are used by the prospective buyers to form expectation about the value of assets, and at equilibrium market prices, people just adjust insufficiently from the anchor set price.

\section{(d). Availability biases}

In some situations, people assess frequency or class of event by recalling that event from past memory. They put more weight on recent events than on past ones. Retrieval memory puts more emphasis in decision makings than non-retrievable memory. Recent events and more salient events distort estimates (Barberis \& Thaler, 2003).Availability bias, however, is caused by the irretrievability of instances, effectiveness of search set in any search engine (also memory), imaginability, and illusory correlation (Kahneman \& Tversky, 1974). 


\section{(e). Optimism and wishful thinking}

People show optimism and wishful thinking once they start trading in the stock market. They have unrealistic rosy overview about the stock market, timing aptitudes, its future prospects, and their own abilities in dealing with the market uncertainty and prospects as well (Weinstein, 1980). They also display fallacy in their systematic investment planning (Barberis \& Thaler, 2003, p. 1066). Further, people may predict that entering into a new stock market or a newly qualified job may be finished too early than they actually are (Buehler et al. 1994). Akerlof and Shiller (2009) argue that investors' optimistic reasoning at emotional outburst may persuade any sector to perceive as valuable or vulnerable. Diether, et al. (2002) have argued that stocks' market prices reflect the most optimistic forecasts in equilibrium pricing mechanism and lead rallies in prices, and thereby facing least growth.

\section{(f). Overconfidence}

Overconfidence is the tendency to overestimate the precision rate of their knowledge (Alpert \& Raiffa, 1982; Brenner et al. 1996) or poorly calibrate odds against any event (Fischhoff, et al. 1977). This generates heterogeneous beliefs among traders and therefore, induces noises in the stocks' equilibrium pricing process (Scheinkman \& Xiong, 2003, p. 228). Overconfidence may also be generated from selfattribution bias and hindsight bias (Barberis \& Thaler, 2003). In the first case, on success (failure) people cheer (blame) their talents (bad luck). Such exercise leads towards self appeasing conclusion over the trading performance (Gervais \& Odean, 2001). In the other bias, however, once an event is occurred people believe that they have predicted it earlier. Daniel, et al. (1998) have shown that stocks' pricing dynamics reflect investors' over (under)-confidence at their private (public) information. Overconfidence (biased self-attribution) suggests for negative (positive) long (short)-lag autocorrelations. In the stock markets with price-taker traders, insider traders, and market makers are over-confident, which enhances the trading volume, and the market depth (Odean, 1999).

\section{(g). Herding}

In herding behavior, investors assume that their own information is of low quality and hence, put less weight. They assume that the other investor predecessors in the market have better quality information and thereby, they have good reasons to react. Thus, they follow actions of the other investors. This behavior generates serious noises, asset price inefficiencies, and misbehaviors. Banerjee (1992) argues that it is rational for the followers to follow the premiers since the latter may have information that is important for the former. Bikhchandani et al. (1992) have shown that fragility arises systematically due to information cascade that happens at some unstable equilibrium. A perfect herding happens if all rational agents act similarly at absence of any countervailing force. Devenowand Welch (1996) have shown that perfect herding arises from direct payoff externalities, principal-agent problems, or informational cascades. If the market as a whole is confused about the current value of assets and quality of information based of traders participated in trades as well, then herd behavior results in irrational short-run price movements significantly (Avery \& Zemsky, 1998). Froot et al. (1992) have shown that at valuable information if investors involve in speculative trading of assets over short-term horizons, then rational speculations may also lead to herding.

\subsection{Preferences}

Besides beliefs, investors' preference influence decision choices. Investors show more sensitivity to difference in utility at current situations over reference levels of assets than those over absolute levels (Helson, 1964). This reference dependence puts forward a few behavioral explanations: disposition effect (Barbaeris \& Xiong, 2009), the prospect theory (Kahneman \& Tversky, 1979, 1984), and the mental accounting (Thaler, 1983; 1999), the theory of ambiguity aversion (Ellsberg, 1961), and that of self-control (Thaler \& Shefrin, 1981). 


\section{(a). The Prospect Theory}

In contrast to the expected utility theory, where all investors are risk-averse, Kahneman and Tversky (1979) have shown that they are risk-averse in terms of profits but risk-acceptant in terms of losses. Investors encode projects' outcomes (that is, prospects) in terms of the reference points and evaluate their pay-offs in terms of gains and losses. Their utility functions are concave (convex) at profits (losses) and are striper for losses than for gains. Around the reference points, they show reflection effect with diminishing sensitivity to changes in assets' value from reference points (Kahneman \& Tversky, 1979 read with Tversky \& Kahneman, 1992). Investors show loss-aversion behavior, where their losses are weighted more heavily than their gains (Kahneman \& Tversky, 1979). They prefer status-quo over bets of equal chances for equal profits or losses (Tversky \& Kahneman, 1991; 1992). Therefore, investors are portrayed by their endowment effects, where they overvalue current holdings and demand more to compensate the same (Kahneman et al. 1990; Thaler, 1980).

Here, investors' face different decision choice problems viz., the certainty effect, pseudo-certainty effect and isolation effect (Kahneman \& Tversky, 1979; 1984), and the framing effect (Tversky \& Kahneman, 1981; 1986). In the first case, they emphasize more on certain outcomes than merely probable outcomes while in pseudo-certainty effect, they put more weight on lesser probable prospects than higher probable ones. In isolation effect, they disregard the shared features of alternative options and focus only on the distinguishing ones. Different decompositions of unique features of prospects may result in different preferences, and it leads to isolation effect. In framing effect, investors' identification of prospects depends on their distance as posed from reference points. Any shift in reference points creates narrow framing, i.e., myopic judgment of circumstances, viz., in evaluating gains or losses, investors consider their available projects narrowly and separately but not along with the total assets' positions. Such narrow framing explains the equity premium puzzle: too high equity risk premiums (Benartzi \& Thaler, 1995). Hence, in sharp contrast to the expected utility theory, the prospect theory offers alternative behavioral descriptions for investors' decision choice problems.

\section{(b). Mental Accounting}

People tend to separate their money into separate accounts based on different subjective notions about the source and uses of money (Kahneman, 1980). They assign different functions to each of the asset groups. More robustly, Thaler $(2008,1983)$ describes that investors (may be fund managers or individuals) follow either explicit (i.e. real) implicit (i.e., mental) accounting system ${ }^{1}$. Mental accounting is defined as "the set of cognitive operations used by individuals and households to organize, evaluate, and keep track of financial activities" (Thaler, 1999; p. 183). It starts with mental coding of the prospects (gains and losses), passes through framing the prospects, then "mental accounting"', and finally, ends with the decision choice (Thaler, 1985; 1999). It includes mental budgeting over different categories of accounts of the incomes, the expenditures, and the wealth. These accounts are non-fungible (i.e., not substitutable) and exposed to the buyer's self-control problems ${ }^{3}$. Mental accounting also has dynamic features. Once the transaction utility ${ }^{4}$ of prospects are perceived experienced, investors segregate them into separate accounts, apply the prospect theory, and set separate reference points in evaluating the profits and losses of the projects (Thaler, 1983; 1999).

\footnotetext{
${ }^{1}$ For details about the origin of the term "mental accounting” see also Thaler and Shefrin (1981), and Tversky and Kahneman (1981).

${ }^{2}$ Here, firstly transaction utility vis-à-vis acquisition utility of a transaction is derived, then accounts are opened and closed at different time intervals, and finally mental adjustments are made for purchases, sunk costs, and payment depreciations and payments are decoupled.

${ }^{3}$ Investors or households often show severe inclination towards luxury gifts than cash money. Self-control problems can influence their choice decisions. In mental accounting, sometimes, budgets are set intentionally low to cover up self-control problem. That is why the best gifts are becoming more luxuries than that at usual consumption.

${ }^{4}$ It represents the perceived value of a 'deal', i.e., "trading money for some object” (Thaler, 1999; p. 188). It is the difference between the money paid by a consumer and the reference price for the object he is ready to pay for it.
} 
This evaluation of prospects, balancing of mental accounts, involves "narrow framing” (Thaler, 1999) or "choice bracketing” (Read et al. 1999) or "loss aversion” (Barberis \& Huang, 2001). Narrow framing refers to evaluation of transaction utility to consumers in isolation and necessarily without any reference to their total wealth. Projects are not are evaluated as parts of overall portfolio rather each at a point of time (Barberis \& Huang, 2001; p. 1249; Thaler, 1999; p. 201). Choice bracketing refers to “...grouping of individual choices together into sets” in fixing the frequency - daily, weekly, fortnightly, etc (Read et al. 1999; p. 172). It suggests that choices are preconditioned by non-fungible notional boundaries and can be altered by changing preconditions. Mental accounting is of beneficial to those investors who are exposed to self-control bias (see latter). In loss-aversion (Kahneman \& Tversky, 1979), however, investors derive utility from their changes in wealth and not that in its absolute levels and they are more sensitive to the decreases in wealth than to the increases. Einio, et al. (2008), and Genesove and Mayer (2001), and Odean (1998b) show that investors regularly deviate from rationality to avoid experiencing regret - the pain associated with making a bad investment or losses.

\section{(c). Disposition Effects}

Investors show preference on holding loser stock too long to that on gainer stocks. They are also reluctant to realize losses (Odean, 1998b). This behavior is called as disposition effect (Shefrin \& Statman, 1985).Investors' disposition effect can generate under-reaction to public news and postannouncement drifts in stock returns (Frazzinii, 2006). Dorn and Strobl (2010) argue that if asymmetric information increases (decreases) less-informed traders prefer to sell (hold) their winner (loser) stocks and therefore, disposition effect is not inconsistent to information based the rational expectation model. $\mathrm{Li}$ and Yang (2013) show that time-varying risk determined by investors' loss aversion attitude leads to effective risk aversion behavior to be positively related to stock returns, and thereby, leading towards disposition effect.

\section{(d). Ambiguity Aversion}

People prefer cash in hand to cash at bank. Today's dividend is more valuable than tomorrow's capital gains (Miller, 1986; p. S451). Keeping apart the time value of money, people in general trend to put higher value for certainty than for uncertainty. Ellsberg (1961) calls this preference as ambiguity aversion. It suggests that the weights on projects' prospects with known probabilities are higher than those with unknown probabilities. It is different from risk aversion attitude and loss aversion ${ }^{5}$. He defines it as "a quality depending on the amount, type, reliability and 'unanimity' of information" that give "rise to one's 'degree of confidence' in an estimate of relative likelihoods” (Ellsberg, 1961; p. 657). It has similarities to regret aversion or risk aversion (Keller et al. 2007). Once people find earlier decisions to be proving wrong, they feel regret but show belief perseverance and hope for the best. They avoid experiencing such regret in repetition. They consistently follow prior strategies even if they go against their well being and avoid mental discomfort with break up strategy. In the sprit of Dow and Werlang (1993), Mukerji and Tallion (2001) show that agents' portfolio diversifications do not eliminate stocks' idiosyncratic risk and ambiguity aversion makes markets incomplete.

\section{(e). Self Control Bias}

Men have "two sets of preferences that are in conflict at a single point in time" (Thaler \& Shefrin, 1981; p. 394) ${ }^{6}$. They impose self-control and constraint their future behaviors. They have dual entities: far

\footnotetext{
${ }^{5}$ Risk aversion refers to investors disliking towards fundamental risks. In the standard finances, active (passive) investors prefer to active (passive) portfolio risk diversification and reduce arbitrage (fundamental) risk. In the prospect theory, investors are loss averse. Here, the losses are weighted more heavily than their gains.

${ }^{6}$ The analysis in Thaler \& Shefrin (1981) is within the standard finance explanations of rational behaviors. Investors' deviation from self-control behaviors which calls for self-control problems and thus, the same aggravates noise in decision making and this requires incorporation in the paper.
} 
sighted planer and myopic doer (Thaler \& Shefrin, 1981). The former is concerned with lifetime utility while the other lives in only for one period. The planner does not consume but derive utility from the consumption of the doer and this characterizes internal conflict similar to the agency conflict between the owners and the managers in a firm (Jensen \& Meckling, 1976). In reducing self-conflict, investors target self-control through rule based or incentives based monitoring. A rule based monitoring leads to saving behavior while an incentive based monitoring sets forth investment behaviors. But at uncertainty, noise holds block information. The planers' regret aversion in realizing losses and much risk acceptance attitudes in the domain of losses induce self-control bias. Another sort of self-control bias is "self-attribution bias" (Daniel, et al. 1998; read with Bern, 1965), where investors attribute favorable outcomes of risky prospects to their own judgment ability but the adverse to bad luck or sabotage.

\section{Empirical Studies and Critics}

The theoretical explanations has put forward that the building blocks (viz., the limits to arbitrage and the traders' psychology) figure up the investors behaviors in the capital markets. This section now explores their empirical evidences and thereby justifies the behavioral finance paradigm.

\subsection{Limits to Arbitrage}

As stated earlier, the limits to arbitrage has four facets viz., the market efficiency, fundamental risks, noise traders' risk, and implementation costs. Now, in contrast to Fama (1998), the limits to arbitrage sets forth huge risks and restricts gaining excess returns at new information. The capital market is neither efficient to excel on arbitrage opportunity at information not it reveals only information (Malkiel, 2003). The short-run serial correlations of returns are non-zero coefficients and there are many successive moves in a direction (Lo \& MacKinlay, 1999). This direction is explained by the technical analysts (Lo et al. 2000). These observations are somewhat different from momentum effect (Odean, 1999), where momentum investors never realize excess returns at transaction costs for its searching. Stocks' returns show strong mean reversion at long-holding horizons ${ }^{7}$ (Poterba \& Summers, 1988; Fluck et al. 1997).There are evidences in favor of seasonal effects ${ }^{8}$.Equity returns are predictable with the initial price earning (P/E) ratios to an extent of 40 percent (Campbell \& Shiller, 1998).There are cross sectional predictable pattern on firm-characteristics (viz., size) and the valuation parameters (viz., Price to Book ratio) as well (Fama \& Frence, 1993; Fama \& Frence, 1997) ${ }^{9}$. Doukas, et al. (2010) show that stocks at high arbitrage risks have greater mispricing than those at low arbitrage risk and arbitrageurs cannot hedge idiosyncratic risk. These findings reject a true random walk. Liu \& Longstaff (2004) have shown that arbitrageurs result in under-investment and even quit from such positioning at margin clearance.

The third contributor to limits to arbitrage is noise traders' risk. French and Roll (1986) acknowledge that the higher variance of the intraday price changes is transitory in nature and is contributed by noise trading by uniformed investors. Podolski, et al. (2009) have shown that noise traders put inadded risk into stock's daily prices and contribute to its volatility but not returns. Koski et al. (2004) have argued that the day traders are noise traders and have shown that these traders increase volatility. In contrast, Kelly (1997) shows that participation by naive investors shows a strong negative predictor of returns while participation by high-income households is a strong positive predictor. In contrast to Sias, et al.

\footnotetext{
${ }^{7}$ Fama and French (1988) found that 25 to 40 percent of the variation in long holding period returns can be predicted in terms of a negative correlation with past returns.

${ }^{8}$ Haugen \& Lakonishok (1988) documented the January effect while French (1980) has showed the Monday effect. Ariel (1990) has confirmed holiday effects.

${ }^{9}$ Even though these observations are in contrast to the prediction of Capital Asset Pricing Model, Lakonishok, et al, (1994) argue that representativeness does not necessarily diminish the notion of market efficiency.
} 
(2001) and Raberto, et al. (2002), DeLong et al. (1990) have shown that noise traders as a group could earn higher returns than rational traders and also survive and dominate the market.

In a theoretical framework similar to Grossman (1976), Aït-Sahaliaand Yu (2009) have shown that noise is positively correlated with intra-day and monthly volatility, spread, transaction size, and effective trading cost while it is negatively correlated with number of intra-day transactions, price level, liquidity ratio, shares outstanding, analyst coverage, and institutional ownership. So \& Wang (2011) confirm that systematic noise traders in a large group with similar perception about movement of future stock prices influence pre-announcement stock prices but are influenced in reverse after news is released. Barber et al. (2003) attribute this systematic noise to behavioral biases such as representativeness heuristic and attention. With tick-by-tick transaction data for the U.S. Stocks, Barber et al. (2006) further confirm that noise trading is systematically correlated and these trades forecast future asset returns if arbitrage by informed traders becomes complicated. With two identical stocks listed in different markets, Scruggs (2007) shows that noise traders' risk has both systematic and firmspecific components while their magnitudes varies over time. Again, with net initiated daily order flow data Berkman and Koch (2008) have examined noise trading in the Australian Stock Exchange and found that their noise measure is positively related to trading volume and market depth while negatively to bid-ask spread. Their monthly movement in noise measure is negatively related to the probability of informed trading but positively to arrival rate of uninformed traders.

Implementation costs which include information cost and trading costs etc. matters in limiting arbitrage opportunity by informed traders. Gemmill and Thomas (2002) have shown that small investment sentiments in the short run drive prices of closed-end funds drive drown from fundamental values while in the long run, noise trading is constrained within upper and lower arbitrages costs. Tuckman and Vila (1992) show that holding costs make apparently low-risk arbitrage to become more-risky. The borrowing costs of a stock may exceed the range of 10 and 15 basis points as envisaged by D'Avolio (2002).With the Hong Kong index futures and index options market data Bae et al. (1998) have shown that larger mispricing arises at larger bid-ask spreads and this restricts possible arbitrage opportunity. Cummings and Frino (2006) analyze mispricing of the Australian stock index futures and find that the ex-ante interest rate volatility induces huge risks to arbitrageurs while the market impact cost of opening index arbitrage positions set forth dynamic influences on revealing fair values. In the line of Kogan et al. (2006), Cvitanic and Malamud (2011) show that noise traders have long-run price impacts and portfolio impacts if their preferences are heterogeneous across agents. Jonesa and Lamont (2002) find short-sale constraints account for $1 \%-2 \%$ lesser returns mostly.

\subsection{Traders’ Psychology}

Traders' psychology consists of belief and preferences. Belief slots in herding, representativeness, conservativeness, anchoring, availability bias, overconfidence, and optimism and wishful thinking. Kaestner (2005) shows that stocks' anomalous prices - overreaction and under-reaction - at different time periods following earnings announcements confirm representativeness bias in the US with longer similar earnings surprises and higher subsequent reversals. Hibbert, et al. (2008) show that negative effect of contemporaneous return on stocks' current implied volatility can also be explained by criteria of representativeness, affect and extrapolation bias rather than leverage or volatility feedback hypothesis only. With the Tehran Stock Exchange trading data, Moradi et al. (2013) find significant correlation between personality types: sensation - intuition, judgment- perceptual and conservatism, and introversion - extraversion and availability bias. Northcraft and Neale (1987) and Bucchianeri and Minson (2013) show that appraised values by different agents are positively related to different anchors or asking prices for the same information on real estate property. In laboratory experiment, Black \& Diaz (1996) find manipulated asking prices influence both buyers' opening offer and eventual transaction price. Earnings forecast also misrepresent stocks' true prices in the equity markets. Mayraz 
(2013) shows that even if there are hedging incentives, optimistic and wishful subjects at high prices expect more rallies in prices to be up-beat than those at low prices.

Zouaoui et al. (2011) with the European countries' data show that consumer confidence index translates into herding behavior and over confidence at times of market crisis. Herding may happen at information cascade (Christoffersen \& Tang, 2009; Radalj \& McAleer, 2003) or at information risks (Boortz et al. 2014). At information asymmetry, herding may happen to markets dominated by irrational individual vis-à-vis rational institutional investors (Devenow \& Welch, 1996; Zhang \& Liu, 2012; Lin et al., 2013; Golec, 1997). Herding makes prices too much bumpy towards breadths and depths at market turmoil and tranquil trading periods (Klein, 2012).Chang et al. (2000) find no evidence of herding behaviors for the US and Hong Kong stock markets but partial evidences in favor of Japan and significant evidence for South Korea and Taiwan stock exchanges. Shih, et al. (2012) have confirmed that the herding effects shows co-movement across the markets in different countries and the Pacific basin stock markets have such effect on the U.S. Dow Jones stock market.

On the prospect theory, Tversky and Kahneman (1992) have shown that investors' loss aversion contributes an S-shaped value function, concave (convex) at gains (losses), along with an inverse probability weighting function at both gains and losses but slightly less curved at losses and more elevated at gains. Abdellaoui (2000), Camerer and Teck-Hua (1994), Etchart-Vincent (2004), Wu, et al. (2005), and Fehr-Duda, et al. (2006) have confirmed the observations of Tversky and Kahneman (1992). Stracca (2002) has shown that risk concentration rather than risk-diversification is a realistic feature in the prospect theory, where an investor is risk seeking over losses. Barbaris and Huang (2008) show that stocks' idiosyncratic risk is priced and positively (negatively) skewed stocks are over (under)-priced leading towards lower (higher) average returns such that investors over (under)-weight stocks’ prices at higher (lower) prices. Boyer et al. (2010), Bali et al. (2011), and Conrad et al. (2014) have confirmed the said observations. Green \& Hwang (2012) have sowed that a higher skewness of initial public offerings is feasible for stocks with lower long-term average returns. Wang et al. (2014) have shown that investors with history of prior loss (capital gain) are exposed to negative (positive) risk-return relationship. On the contrary, Wu and Markle (2007) find violation of the double matching axiom in gain-loss separability in mixed gambles. A strong risk aversion implies S-shaped weighting function and it does not necessarily show concavity in the utility function (Schmidt \& Zank, 2008).

On mental accounting, Arkes et al. (1994) and Milkman and Beshears (2008) have shown that consumers in laboratory experiments spend more out of their unexpected income than that out of anticipated income. Propensity to spend windfall income is larger than that to regular income and the former decreases as the windfall size increases (Bodkin, 1959; Bird \& Bodkin, 1965; Keeler et al. 1985). Baker et al. (2007) show strong response of consumption to the receipt of dividends once effects of stock return is controlled for. Investors in the real estate mitigate regret aversion for losses in an asset class by a higher return on overall portfolio as if they feel better off (Seiler \&Lane, 2010). Barberis and Huang (2001) have shown that mental accounting significantly influences stocks' asset prices and in equilibrium frameworks from "individual stock accounting” to "portfolio accounting”, stocks' returns falls, their volatility diminishes, they becomes more inter-correlated while in the cross section huge premium as argued in the equity premium puzzle disappears (p. 1249). Mental accounting has implications also on investors' myopic loss-averse behaviors, where high frequency evaluations of gains and loses result in greater discomfort than low frequency evaluation (Haigh \& List, 2005).

Investors' preferences include disposition effects, the prospect theory, mental accounting, ambiguity aversion, and self control bias. In a formal relationship between disposition effect and prospect theory, Barberis and Xiong (2009) have shown that realized gains or losses can predict disposition effect more reliably than annual gains or losses. Shefrin and Statman (1985) have examined investors' “disposition effect" - how they sell the winner stocks and hold the looser ones at high and low prices respectively. They include these aspects along with regret aversion and tax consideration. Seiler and Lane (2010) 
find that only $6.8 \%$ respondents show complete rationality while $74.9 \%$ are more willing to sell as the return on investment rises. They find that an $S$-shaped disposition curve does not hold for all investors and $7.3 \%$ respondents show a $U$-shaped curve. The other studies on disposition effect are Kaustia (2010), Birru (2011), Einio et al. (2008), Grinblatt and Han (2005), Ivkovich et al. (2005), Grinblatt and Keloharju (2001), Shapira and Venezia (2001), Benartzi and Thaler (1995), and Heisler (1994). Weber and Camererb (1998) show that subjects show multiple reference points and prefer selling fewer stocks at bellow purchase price (falling prices) to above purchase price (rising prices).

Ambiguity aversion is another important preferential behavior. It is different from risk aversion and loss aversion as wellsince investors' framing and reference points put influence on their decision making (Wakker, 2010, p. 435). Hansen (2007) has shown that if certain conditions are fulfilled then, the prices of risky (uncertain) choices depend on risk (ambiguity) aversion parameters. Once individuals evaluate prospects of single gamble in non-comparative setting, ambiguity aversion may disappear (Fox \& Tversky, 1995) while ambiguity aversion reduces at separate evaluations (Chow \& Sarin, 2001). Sarin \& Weber (1993) show that in market settings, ambiguity aversion fades in independent auctions rather than in simultaneous ones. In the international finance, Kirabaeva (2009) has shown that ambiguity aversion may be used in order to explain investors' equity home bias ${ }^{10}$.

On self control bias, there are little empirical works in the behavioural finance literature. Individuals differ in self-control while they are more sensitive at under-consumption than over-consumption (Ameriks, et al. 2007).Huffman \& Bonn (2005) have shown that individuals tend to borrow rather than exhibit credit constraints. Further, Cho and Rust (2013) have shown that at zero percent interest rate for purchase through credit cards, consumers have financial self control problems and resist the temptation.

\section{Synthesis of the Puzzles}

In the finance literature, puzzle stands for phenomena which could not be put in words by the rational expectations and the expected utility framework. The known standard finance puzzles are (i) the stock price under-/over-reactions, (ii) the excessive trading and gender puzzle, (iii) the financial hypes and panics,(iv) the equity premium puzzle, (v) the winner/loser puzzle, and (vi) the dividend puzzle.

Firstly, overreaction suggests that stock markets react immediately to news releases but wane up gradually while at under-reaction, markets continues to resonate. The empirical studies suggest that stock markets rarely react accurately to information rather they most frequently depict over- /underreactions (Barberis, et al. 1998). At initial release of earnings announcements, the surprise element of returns has positive impact on stock price rises(Bernard, 1992).With stocks' monthly return data, DeBondt and Thaler (1985) have empirically showed that "...people tend to "overreact” to unexpected and dramatic news events.” Cutler, et al. (1991) have shown that stock-returns are positively serially correlated at high frequencies, negatively correlated over long horizons, and their deviations from fundamental values have predictive power. In a rational expectation equilibrium model, Veronesi (1999) has shown that investors' hedging against their mental uncertainty about future states results in stock price over (under)-reaction at bad (good) news. Kaestner (2005) confirms that representativeness bias makes stocks' prices anomalous at earnings announcements. On synthesizing the puzzle, Daniel, et al. (1998) and Chuang and Lee (2006) have showed that over (under)-confidence flapped (suppressed) by self-attribution bias initiates over (under)-estimation of precision of private (public) information signals and leads to over (under)-reaction. Series of continuing over (under)-reaction to

\footnotetext{
${ }^{10}$ It refers to the disparity in investors' actual portfolio weights and the weights under the international capital asset market model. Under certain conditions, the model suggests weights of assets in the portfolio to be in proportion to their market capitalization. However, the investors show a greater exposure to the domestic assets (see also, French \& Poterba, 1991; and Tesar \& Werner, 1995).
} 
private (public) information signal result in negative (positive) autocorrelation. Conservatism (representativeness heuristic) can explain stocks' under (over)-reaction to news (Barberis, et al. 1998; Kaestner, 2005). George and Hwang (2004), and Li and Yu (2009) have shown that overreaction and under-reaction can also be explained by psychological anchors viz., 52 weeks’ high / low stocks.

Secondly, how many shares or how frequently one should trade at information? Does he trade highly or normally or lowly or rationally? These queries hint for anomaly in the Efficient Market Hypothesis. Investors' greater overconfidence about precision levels of information and knowledge motivates to trade huge in volume but lowers their expected utility (Odean, 1998a). Barber and Odean (2000) have shown that in the stock markets, average traders trade too much while they enjoy less returns than the less frequent traders. Barber and Odean (2001) find that men are more overconfident to trade more than women by 45 percent while trading reduces their net returns.Griffin et al. (2007) and Chuang and Susmel (2010) have confirmed that over (under)-confidence can explain excessive (low) trading volume at market rally (recovery).

Thirdly at presence of noise in the capital markets, firms and investors react differently at different financial innovations by management. They react differently at different firm-specific and marketspecific unexpected news / events (Calomiris \& Mason, 1997; Keijer \& Prast, 2001).In effect, events those attract (destroy) investors' feeling of confidence and perceived controls of the financial markets create financial hypes (panics) in the markets (Kindleberger \& Aliber, 2005; Goldstein \& Razin, $2012)^{11}$. Hype means rumour created by market maker or information media while panic refers to strong negative motivation for protective actions. At bank runs, investors shift their expectations (Diamond \& Dybvig, 1983). Since the payoff externalities of depositors in the banking sector force them to respond to early noisy information, instances of failure of a few banks may trigger contagious runs (Chen, 1999).Financial panic is an emotional outbreak and it does not go with existing market information (Bracha \& Weber, 2012). Financial hype (panic) can be created by market makers at market rally (crash). At information cascade, investors' asymmetric (symmetric) aggregation may result into negative (positive) herding at financial panic (hype) viz., market crash (market rally) (see, Smith \& Soerensen, 2000).

The equity premium puzzle infers that average equity returns exceed highly to average risk-free returns while such results are unexplainable by the Arrow-Debreu general equilibrium theory (Mehra \& Prescott, 1985; Siegel \& Thaler, 1997). The too high (low) average returns of the equity (debts) attract serious criticisms against the standard finance theories. There are a few studies in the standard finance viz., Constantinides (1990), Mankiw and Zeldes (1991), and Fisher (1994). The former suggests habitformation model where utility of any consumption depends on past consumption levels, the second analyzes consumption-based homogeneity assumption for individuals in stock markets vis-à-vis noninvestors thereof while the third argues that presence of transaction and trading costs are to be adjusted in smoothing gross returns. These studies could explain a little. In behavioral finance, myopic loss aversion of Benartzi and Thaler (1995), dynamic loss aversion of Barberis, et al. (2001), and ambiguity aversion of Mukerji (1998) and Keller, et al. (2007) forward ingenious arguments. The "myopic lossaversion” suggests that investors are "myopic" in mental accounting (they evaluate long-term projects along with short-term performances) and "loss-averse" at different prospects (they overemphasize losses than gains). In dynamic loss-aversion, investors derive utility from direct consumption and indirect fluctuations in prices. Investors are loss-averse over changes in prices while loss-averse depends on prior investment performances. However in ambiguity aversion, investors' subjective beliefs are represented by probability functions while investors adjust the same at risky choices.

11Kindleberger \& Aliber (2005) define financial panic as "sudden fright without a cause that may occur in asset markets". Goldstein \&Razin (2012) defines it as "crises not justified solely on the basis of fundamentals". 
The winner / loser puzzle suggests that investors tend to sell their winner stocks more often than their loser ones while the standard finance suggests the reverse for tax reasons (Odean, 1998b). Shefrin and Statman (1985) explain the puzzle with a general disposition effect along with the arguments of prospect theory, mental accounting, regret aversion, and self control. Prospect theory inhibits disposition to ride or hedge the losers with the gainers rather than indulging in subsequent gamble with the latter. Mental accounting sets forth robustness to prospects once disposition being realized is reinvested. Regret aversion confirms different treatment for gainers to losers while self-control restrains form realizing losers. Odean (1998b) and Shefrin (2002a, 2000b) empirically confirm the argument of Shefrin and Statman (1985).In experimental research,Weber and Camererb (1998) have shown that subjects sell their winner stocks more frequently than their loser ones and have confirmed that prospect theory may explain the puzzle.With real investment data set, Hens and Vlcek (2011) have criticised that investors in Kahneman and Tversky (1979) and Tversky and Kahneman (1992) do not invested in those stocks primarily, which they are presently willing to hold or sell, since their ex-post behaviour is contrary to their ex-ante behaviours. Prasad and Mohta (2012) have shown that even if both individual and professional investors are exposed to disposition effect in the Indian stock markets but the latter are less inclined to. Strobl (2003) has put forth a new argument that the degree of information asymmetry contributes to investors' tendency to the said effect such that higher is the information asymmetry higher is the tendency to sell the winner stocks and to hold the loser stocks.

Finally, the dividend puzzle suggests that investors prefer cash dividends to capital gains in the form of price appreciations in the market even if the former attracts taxes at higher rates (Long, 1978; Miller \& Scholes, 1982). Investors with their incomes in tax-brackets should prefer capital gains to dividends while at exempted bracket, they should either be indifferent between the two forms of income or assume those stocks to be perfectly substitutes in rebalancing their investment portfolios. The signaling theory of dividend in Bhattacharya (1979) explains a little of the puzzle (Brealey \& Myers, 1981).In the behavioral finance, the mental accounting along with either self-control problem (Thaler \& Shefrin, 1981)or regret-aversion attitude (Kahneman \& Tversky, 1982) or loss-aversion couple with narrow framing (Barberis \& Huang, 2008) can explain the dividend puzzle. According to Thaler and Shefrin (1981), investors face self-control problem in managing immediate gratifications and attribute more weights to dividends than that to price appreciations. Shefrin (2002) also suggests that investors' references to separate mental accounts for dividend income and capital gains alleviate investors' self control dilemma to reach capital conservation and consumption out of dividend. At the rally (bear) to the stocks' prices, Statman (1999) argues that cash dividend plays as an extra gain ('silver lining' or buffer support) to appreciations (falls) in stocks' prices. Kahneman and Tversky (1982) suggest that consumption out of sale of a stock creates more frustration than that out of dividend receipts since holding a gainer stock may conserve future flow of dividends as well. Barberis and Huang (2008) argue that investors frame purchase price instead of ex-announcement higher market price as their reference price in calculating the ex-post rate of return and thus prefer dividends to capital gains.

\section{Research Gaps}

On the stocks' pricing dynamics, Information, and noise specific researches are required to identify the role of both noise and information in the dynamic equilibrium pricing mechanisms. Since traders include both buyers and sellers and they trade in various assets in the market, the works of Banerjee (1992) and Bikhchandani, et al. (1992) need to be re-examined at presence of both sides' information cascade in the dynamic equilibrium process across different assets. In Grossman and Stiglitz (1980), Black (1986), and DeLong et al. (1991) presence of noise persists but they have not identified the extents of noise in the market as a whole and its roles at market rally or market distress. The role of behavioral biases and psychology in stocks' dynamic pricing mechanism in determining the extent of noise and information is mostly missing in the literature. On the equilibrium pricing dynamics, information and noise, there is vast literature on experimental researches but little studies are done on the empirical front. Particularly, definition of noise vis-à-vis information and their identifications with 
data put forth serious research gaps in the empirical literature. Finally, the role of the limits to arbitrage and traders' psychology in synthesizing the above puzzles is not examined in the empirical literature as yet.

The premier studies on behavioral finance, however, are almost done in the developed countries' contexts. On the association between the per capita income and the level of happiness (risk), Statman (2008) show that the Indian investors rank above (bellow) the general tendency curve even if they belong to moderate associations. Iyer and Bhaskar (2002) have explored the role of psychology in investors' stock trading behaviors in India. Prosad et al. (2012) find evidences in favor of the standard finance implications and rejects herding behaviors in Indian markets. Sahni (2012) has explored the loss aver-ness behaviors and the effects of anchoring on the Indian stock traders. Subhas (2012) has shown that the younger investors in the Indian stock markets show regret aversion, gamblers' fallacy and hindsight bias while the experienced investors could be separated with lesser degree to erroneous decisions. Chandra (2009) has shown evidences for individual investors' self-perceived competences and own-judgments. Kathuria and Singhania (2012) have explored implications of gender in stock trading in India. Campbell et al. (2013) have shown that experienced investors tilt their portfolios profitably towards value stocks and those stocks with low turnover while they tend to have lower turnover and disposition bias.

These studies offer contradictory evidences while they have utilized either the opening or the closing price data of stocks' trading. The studies have missed the role of "noise" i.e., liquidity traders in the stocks' price formation process. Possible exploration of the experimental studies is another grave research area on the Indian context. The behaviors of investors in stock markets as well are expected to be dynamic by nature. No single theory is expected to provide explanations those are all encompassing. At presence of liquidity traders, dynamics in the equilibrium pricing mechanisms with noise and information may address the unsettled research queries.

\section{Conclusion}

In stocks’ pricing dynamics, "noise” vis-à-vis information has critical roles to play and thereby shape the investors' behaviors. Both the noise and information have economic and non-economic effects. How both the causes and the effects persist over "time" and "space", "space" refers to investors" decision frames, is an evolutionary research query. Grossman and Stiglitz (1980), and Lee (2001) have emphasized about the enduring presence of noise vis-à-vis information in the investors' dynamic journey in discovering the equilibrium pricing and not the destination. On empirical tranquility, a valid conclusion is subject to valid theoretical arguments, empirical data set, tools for testing, and development of human knowledge bases to analyze the above. In particular, the series of daily stocks' price data (either it be the open price, or the close price, or the highest price, or the lowest price) or the NAV value (based on the closing prices of the underlying assets) of the units of Mutual funds have lesser predictive power about investors behaviors along the trading day. The investors are heterogeneous in classes and of course, with specific individual backgrounds and economic objectives. The researches in behavioral finance are promising paradigm shifts in the human knowledge but till date, it needs further studies. The present work could be concluded with the following afresh lines in Black (1986).

"A person with information or insights about individual firms will want to trade, but will realize that only another person with information or insights will take the other side of the trade. Taking the other side's information into account, is it still worth trading? From the point of view of someone who knows what both traders know, one side or the other must be making a mistake. If the one who is making a mistake declines to trade, there must be no trading on 
information. In other words, I do not believe it makes sense to create a model with information trading but no noise trading ...” [Black (1986, p. 531)].

\section{References}

Abdellaoui, M. (2000). Parameter-free elicitation of utility and probability weighting functions. Management Science, 46(11), 1497-1512.

Aït-Sahalia, Y., \& Yu, J (2009). High frequency market microstructure noise estimates and liquidity measures. The Annals of Applied Statistics, 3(1), 422-457.

Akerlof, G. A., \& Shiller, R. J. (2009). Animal spirits - How human psychology drives the economy and why it matters for global capitalism. Princeton: Princeton University Press. Source: http://press.princeton.edu/chapters/i8967.html

Alpert, M., \& Raiffa, H. (1982). A progress report on the training of probability assessors. In: Kahneman, D., Slovic, P., \& Tversky, A. eds., Judgment under uncertainty: Heuristics and biases, Cambridge University Press, Cambridge, 294-305.

Ameriks, J., Caplin, A, Leahy, J., \& Tyler, T. (2007). Measuring self-control. The American Economic Review, 97(3), 966-972

Ariel, R. A. (1990). High stock returns before holidays: Existence and evidence on possible causes. Journal of Finance, 45(5), 1611-626.

Arkes, H.R., Joyner, C.A., Pezzo, M.V., Nash, J.G., Siegel-Jacobs, K., \& Stone, E., (1994). The psychology of windfall gains. Organizational Behavior and Human Decision Processes, 59(3), 331-347.

Avery, C., \& Zemsky, P. (1998). Multi-dimensional uncertainty and herd behavior in financial markets. The American Economic Review, 88(4), 724-748.

Bae, K. H., Chan, K., Cheung, Y. L. (1998). The Profitability of Index Futures Arbitrage: Evidence from Bid-Ask Quotes. Source: http://home.ust.hk/ kachan/research/arbitrage.pdf

Baker, M., Nagel, S., \& Wurgler, J., (2007). The effect of dividends on consumption. Brookings Papers on Economic Activity, 1, 231-276.

Bali, T. G., Cakici, N., \& Whitelaw, R. F. (2011). Maxing out: Stocks as lotteries and the cross-section of expected returns. Journal of Financial Economics, 99(2), 427- 446.

Banerjee, A. V. (1992). A simple model of herd behavior. The Quarterly Journal of Economics, 107(3), 797-817.

Barber, B. \& Odean, T. (2000). Trading is hazardous to your wealth: The common stock investment performance of individual investors. The Journal of Finance, 55(2), 773-806.

Barber, B. \&Odean, T. (2001). Boys will be boys: Gender, overconfidence and common stock investment. Quarterly Journal of Economics, 116(1), 261-292

Barberis, B. M., Odean, T., \& Zhu, N. (2003). Systematic Noise. Journal of Financial Markets, 12(4), 547569

Barberis, B. M., Odean, T., \& Zhu, N. (2006). Do Noise Traders Move Markets? EFA 2006 Zurich Meetings Paper, http://papers.ssrn.com/sol3/papers.cfm?abstract_id=869827

BARBERIS, N. \& XIONG, W. (2009). What drives the disposition effect? An analysis of a long-standing preference-based explanation. The Journal of Finance, 64(2), 751-784.

Barberis, N., \& Huang, M. (2001). Mental accounting, loss aversion, and individual stock returns. The Journal of Finance, 56(4), 1247-1292.

Barberis, N., \& Huang, M. (2008). Stocks as lotteries: The implications of probability weighting for security prices. The American Economic Review, 98(5), 2066-2100.

Barberis, N., \&Thaler, R. (2003). A Survey of Behavioral Finance, in Handbook of the Economics of Finance, Edited by G.M. Constantinides, M. Harris and R. Stulz. Elsevier Science B.V.

Barberis, N., Huang, M.,\& Santos, T. (2001). Prospect theory and asset prices. Quarterly Journal of Economics, 116(1), 1-53.

Barberis, N., Shleifer, A., \&Vishny, R. (1998). A model of investor sentiment. Journal of Financial Economics, 49(2), 307-343.

Benartzi, S., \&Thaler, R. (1995). Myopic loss aversion and the equity premium puzzle, Quarterly Journal of Economics, 110(1), 73-92. 
Berkman, H., \& Koch, P. D. (2008). Noise trading and the price formation process. Journal of Empirical Finance, 15(2), 232-250.

Bern, D. J. (1965). An experimental analysis of self-persuasion. Journal of Experimental Socialpsychology. 1(3), 199-218.

Bernard, V. L. (1992). Stock price reactions to earnings announcements: A summery of recent anomalous evidence and possible explanations. Working Paper $\quad$ No. 703. http://deepblue.lib.umich.edu/bitstream/handle/2027.42/35405/?sequence=2

Bhattacharya (1979). Imperfect information, dividend policy, and the bird in the hand fallacy. The Bell Journal of Economics, 10(1), 259-270.

Bikhchandani, S., Hirshleifer, D., \&Welch, I. (1992). A theory of fads, fashion, custom, and cultural change as informational cascades. Journal of Political Economy, 100(5), 992-1026.

Bird, R., \& Bodkin, R.G. (1965). The national life-insurance dividend of 1950 and consumption: A further test of the 'strict' permanent-income hypothesis. Journal of Political Economy, 73(5), 499 - 515.

Birru, J. (2011). Confusion of confusions: A test of the disposition effect on momentum, Proceedings of the 2011 Annual Meeting of the Academy of Behavioral Finance and Economics, September 21-23, 2011, Los Angeles, California.www.aobf.org/ssl/attachments/2011/ABF_2011_Proceedings_Book.pdf

Black, F. (1986). Noise. The Journal of Finance, 41(3), 529 - 543.

Black, R., \& Diaz, J. III. (1996). The use of information versus asking price in the real property negotiation process. Journal of Property Research, 13(4), 287-297.

Bodkin, R.G. (1959). Windfall income and consumption. The American Economic Review, 49(4), 602-614.

Bokhari, S. \&Geltner, D. (2010). Loss aversion and anchoring in commercial real estate pricing: Empirical evidence and price index implications. Source: http://papers.ssrn.com/sol3/papers.cfm?abstract_id=1599382

Boortz, C., Kremer, S., Jurkatis, S., \&Nautz, D. (2014). Information risk, market stress and institutional herding in financial markets: New evidence through the lens of a simulated model. SFB 649 Discussion Paper 2014-029. http://sfb649.wiwi.hu-berlin.de/papers/pdf/SFB649DP2014-029.pdf

Boyer, B., Mitton, T., \&Vorkink., K. (2010). Expected idiosyncratic skewness. Review of Financial Studies, 23(1), $169-202$.

Bracha, A., \& Weber, E. U. (2012). A psychological perspective of financial panic. FRB of Boston Public Policy Discussion Paper No. 12-7, Source: http://papers.ssrn.com/sol3/papers.cfm?abstract_id=2192183\#\#

Brealey, R, and S. Myers (1981), Principles of corporate finance, Mc Graw Hill, New York.

Brennan, M. (1993). Agency and asset prices. Finance Working Paper No. 6-93, UCLA.

Brenner, L., Koehler, D., Liberman, V. \& Tversky, A. (1996). Overconfidence in probability and frequency judgments. Organizational Behavioral and Human Decision Processes, 65(3), 212-219.

Bucchianeri, G.W., \& Minson, J., (2013). A homeowner's dilemma: Anchoring in residential real estate transactions. Journal of Economic Behavior \& Organization, 89(6), 76-92. doi: 10.1016/j.jebo.2013.01.010.

Bucher, M., \& Woehrmann, P. (2006). Survival of noise traders and the implications for asset prices, Working paper, Source w: http://andromeda.rutgers.edu/ jmbarr/NYComp/woehrmann.pdf

Buehler, R., Griffin, D., \& Ross, M. (1994). Exploring the planning fallacy: Why people underestimate their task completion times. Journality of Personality and Social Psychology, 67(3), 366-381.

Calomiris, C. W. \& Mason, J. R. (1997). Contagion and bank failures during the great depression: The June 1932 Chicago banking panic. The American Economic Review, 87(5), 863-883

Camerer, C. F., \& Teck-Hua, H. (1994). Violations of the betweenness axiom and nonlinearity in probability. Journal of Risk and Uncertainty, 8(2), 167-196.

Campbell, J. Y. \& Shiller, R. J. (1998). Valuation ratios and the long-run stock market outlook, Journal of Portfolio Management, 24(2), 11-26.

Campbell, J.Y., \& Kyle, A. (1988). Smart money, noise trading, and stock price behavior. NBER Technical Working Paper No. 71. Source: http://www.nber.org/papers/t0071

Campbell, J.Y., Ramadorai, T., \& Ranish, B., (2013). Getting better: learning to invest in an emerging stock market. http://www.people.fas.harvard.edu/ branish/papers/StockTraderLearning.pdf

Chandra, A. (2009). Individual investors' trading behavior and the competence effect. The ICFAI University Journal of Behavioral Finance, 6(1), 56-70 
Chang, E. C., Cheng, J. W., \& Khorana, A. (2000). An examination of herd behavior in equity markets: An international perspective. Journal of Banking \& Finance, 24(10) 1651-1679.

Chen, Y-N., (1999). Banking panics: The role of the first-come, first-served rule and information externalities. Journal of Political Economy, 107(5), 946-968

Cho, S.J. \& Rust, J. (2013) Precommitments for financial self-control: Evidence from credit card borrowing. Source: http://www.econ.ku.dk/cam/calendar/seminars/20082013/ccsc.pdf

Chow, C. C. \& Sarin, R. K. (2001). Comparative ignorance and the Ellsberg paradox. Journal of Risk and Uncertainty, 22(2), 129-139.

Christoffersen, S., \& Tang, Y., (2009). Institutional herding and information cascades: Evidence from daily trades. Source: https://www.mcgill.ca/files/desautels/YaTang-JobMarketPaper.pdf

Chuang, W. I., \& Lee, B. S. (2006). An empirical evaluation of the overconfidence hypothesis. Journal of Banking and Finance, 30(9), 2489-2515.

Chuang, W. L. \& Susmel, R. (2010). Who is the more overconfident trader? Individual vs. institutional investors, Journal of Banking \& Finance, 35(7) 1626-1644

Conrad, J., Dittmar, R. F., \& Ghysels, E. (2014). Ex-ante skewness and expected stock returns. Journal of Finance, 68(1), 85-124.

Constantinides, G. M. (1990). Habit formation: A resolution of the equity premium puzzle. Journal of Political Economy, 98(3), 510-543.

Corner, A., Harris, A. J. L, Hahn, U. (2010) Conservatism in belief revision and participant skepticism. Working Paper, Source: http://www.ucl.ac.uk/lagnado-lab/publications/harris/cornerEtAl2010.pdf

Corner, A., Harris, A. J. L., \& Hahn, U. (2010). Conservatism in belief Revision and Participant Skepticism, In: Ohlsson, S and Catrambone, R, (eds.) Proceedings of the 32nd Annual Conference of the Cognitive Science Society, 1625-1630.

Cummings, J. R., \& Frino, A., (2006). Index arbitrage and the pricing relationship between Australian stock index futures and their underlying shares. http://www.fma.org/Texas/Papers/IndexArbitrage.pdf

Cutler, D., Poterba, J. \& Summers, L. (1991). Speculative dynamics. Review of economic studies, 58(3), 529-546.

Cvitanic, J., \& Malamud, S. (2011). Price impact and portfolio impact. Journal of Financial Economics, 100(1), 201-225.

D’Avolio, G. (2002). The market for borrowing stock. Journal of Financial Economics, 66(2-3), 271-306.

Daniel, K., Hihleifer, D., \& Subramanyam, A. (1998). Investor Psychology and Security Market Underand Overreactions. Journal of Finance, 53(6), 1839-1885.

De Bondt, W. F. M. \& Thaler, R. (1985).Does the stock market overreact? The Journal of Finance, 40(3), 793-805.

DeLong, J. B. (2005). Financial markets, noise traders, and fundamental risk: Background memo. U.C. Berkeley and NBER. http://citeseerx.ist.psu.edu/viewdoc/download?doi=10.1.1.186.746\&rep=rep1\&type=pdf.

DeLong, J. B., Shleifer, A., Summers, L. H., \& Waldmann, R. J. (1991). The survival of noise traders in financial markets. Journal of Business, 64(1), 1-19.

DeLong, J.B., Shleifer, A, Summers, L. H., \& Waldmann, R. J. (1990). Noise trader risk in financial markets. The Journal of Political Economy, 98 4). 703-738.

Devenow, A., \& Welch, I. (1996). Rational herding in financial economics. European Economic Review, 40(3-5) 603-615

Diamond, D. W. \& Dybvig, P. H. (1983). Bank runs, deposit insurance, and liquidity, Journal of Political Economy, 9(3), 401-419

Diether, K., Malloy, C., \& Scherbina, A. (2002). Differences of opinion and the cross section of stock returns, The Journal of Finance, 57(5), 2113-2141

Dorn, D.\&Strobl, G. (2010). Rational disposition effects: Theory and evidence. Drexel University Working Paper. Source: http://faculty.lebow.drexel.edu/dornd/dispeffemp.pdf

Doukas, J.A., Kim, C., \& Pantzalis, C (2010). Arbitrage risk and stock mis-pricing. Journal Of Financial and Quantitative Analysis, 45(4), 907-934

Dow, J., \& Werlang, S. R. (1993). Uncertainty aversion, risk aversion, and the optimal choice of portfolio, Econometrica, 60(1), 197-204.

Edwards, W. (1954). The theory of decision-making. Psychological Bulletin, 51(4), 380-417. 
Edwards, W. (1968). Conservatism in human information processing. In: B. Kleinmutz, ed., Formal Representation of Human Judgment (Wiley, New York). 17-52.

Einio, M., Kaustia, M., \& Puttonen, V. (2008). Price setting and the reluctance to realize losses in apartment markets, Journal of Economic Psychology, 2008, 29(1), 19-34.

Ellsberg, D. (1961). Risk, ambiguity, and the savage axioms. Quarterly Journal of Economics, 75(4), 643669.

Etchart-Vincent, N. (2004). Is probability weighting sensitive to the magnitude of consequences? An experimental investigation on losses. Journal of Risk and Uncertainty, 38(3), 217-235.

Fama, E. F. (1965). The behavior of stock market prices. Journal of Business, 38(1), 34-105.

Fama, E. F. (1991). Efficient capital markets: II. The Journal of Finance, 46(5), 1575-1617

Fama, E. F. (1998). Market efficiency, long-term returns, and behavioral finance, Journal of Financial Economics, 49(3), 283-306.

Fama, E., \& French, K. (1993). Common risk factors in the returns on stocks and bonds. The Journal of Finance. 33(1), 3-56.

Fama, E., \& French, K. (1997). Value vs. growth: The international evidence. The Journal of Finance, 53(6), 1975-1999.

Fama, E., \& French, K. R. (1988). Permanent and temporary components of stock prices. Journal of Political Economy, 96(2), 246 -273.

Fehr-Duda, H., De Gennaro, M., Schubert, R. (2006). Gender, financial risk, and probability weights. Theory and Decision, 60(2-3), 283-293.

Fischhoff, B., Slovic, P., \& Lichtenstein, S. (1977). Knowing with certainty: The appropriateness of extreme confidence. Journal of Experimental Pyschology: Human Perception and Performance, 3(4), 552-564.

Fisher, S. J. (1994). Asset trading, transaction costs and the equity premium. Journal of Applied Econometrics, 9(1), S71-S94.

Fluck, Z., Malkiel, B., \& Quandt, R. (1997). The predictability of stock returns: A cross-sectional simulation. Review of Economics and Statistics. 79(2), 176 -83.

Foster, F. D., \& Viswanathan, S. (1990). A theory of the interday variations in volume, variance, and trading costs in securities markets. The Review of Financial Studies, 3(4), 593-624

Fox, C. \&Tversky, A. (1995). Ambiguity aversion and comparative ignorance, The Quarterly Journal of Economics, 110(3), 585-603

Frazzinii, A. (2006). The disposition effect and underreaction to news. The Journal of Finance, 61(4), 20172046.

French, K. \& Poterba, J (1991). International diversification and international equity markets. The American Economic Review, 81(2), 222 -226.

French, K. R. (1980). Stock returns and the weekend effect. Journal of Financial Economics, 8(1), 55-69.

French, K., \& Roll, R. (1986). Stock return variances: The arrival of information and the reaction of traders, Journal of Financial Economics. 17(1), 5-26.

Friedman, M. (1953). The case for flexible exchange rates. In Essays in Positive Economics. Chicago University Press.

Froot, K. A., Scharfstein, D. S. \& Stein, J. C. (1992). Herd on the Street: Informational inefficiencies in a market with short-term speculation. The Journal of Finance, 47 4), 1461-1484.

Gemmill, G., \& Thomas, D. C. (2002). Noise-trading, costly arbitrage, and asset prices: Evidence from closed end funds. Working Papers Series, WP02-09, Source: http://wrap.warwick.ac.uk/1804/1/WRAP_Gemmill_fwp02-09.pdf.

Genesove,D. \& Mayer, C. (2001). Loss aversion and seller behavior: Evidence from the housing market. The Quarterly Journal of Economics, 116(4), 1233-1260.

George, T.J., \& Hwang, C. Y. (2004). The 52-week high and momentum investing, The Journal of Finance, 59(5), 2145-2176

Gervais, S., \&Odean, T. (2001). Learning to be overconfident. Review of Financial Studies, 14(1), 1-27.

Goldstein, I. \& Razin, A. (2012). Review of theories of financial crises. Source: http://citeseerx.ist.psu.edu/viewdoc/download?doi=10.1.1.230.7172\&rep=rep1\&type=pdf

Golec, J. (1997). Herding on noise: The case of Johnson Redbook's weekly retail sales data. Journal of Financial and Quantitative Analysis, 32(3), 367-381 
Green, T. C., \& Hwang, B. H. (2012). Initial public offerings as lotteries: Skewness preference and firstday returns. Management Science, 58(2), 432- 44.

Griffin, m. A., Neal, a., \& Parker, s. K. (2007) A new model of work role performance: Positive behavior in uncertain and interdependent contexts. Academy Of Management Journal, 50(2), 327-347.

Grinblatt, M., \& Han. B. (2005). Prospect theory, mental accounting, and momentum. Journal of Financial Economics, 78(2), 311-339.

Grinblatt, M., \& Keloharju, M. (2001). What makes investors trade? The Journal of Finance, 56(2), 589616.

Grossman, S. (1976). On the efficiency of competitive stock markets where traders have diverse information. The Journal of Finance, 32(2), 573-585.

Grossman, S., \& Stiglitz, J. (1976). Information and competitive price system. American Economic Review, 66(2), 246-253.

Grossman, S., \& Stiglitz, J. (1980). On the impossibility of informationally efficient markets. The American Economic Review, 70(3), 393-408.

Haigh, M. S., \& List, J. A. (2005). Do professional traders exhibit myopic loss aversion? An experimental analysis, The Journal of Finance, 60(1), 523-534.

Hansen, L. P. (2007). Beliefs, doubts and learning: Valuing macroeconomic risk. The American Economic Review, 97(2), 1-30.

Haugen, R. A., \&Lakonishok, J. (1988). The incredible January effect: The stock market's unsolved mystery. Dow Jones-Irwin.

Heisler, J. (1994). Loss aversion in a futures market: An empirical test, Review of Futures Markets, 13(4), 793-822.

Helson, H. (1964). Adaptation-level theory: An experimental and systematic approach to behavior. Harper and Row: New York.

Hens, T., \& Vlcek, M. (2011). Does prospect theory explain the disposition effect? Journal of Behavioral Finance, 12(3), 141-157

Hibbert, A. M., Daigler, R. T., \& Dupoyet, B. (2008). A behavioral explanation for the negative asymmetric return - volatility relation. Journal of Banking \& Finance, 32(10), 2254-2266

Holden, C. W., \& Subrahmanyan, A. (1992). Long-live private information and imperfect competition. The Journal of Finance, 47(1), 247-270.

Huberman, G., \& Halka, D. (2001). Systematic liquidity. Journal of Financial Research, 24(2), 161-178

Huffman, D., \& Bonn, I (2005). A monthly struggle for self-control? Hyperbolic discounting, mental accounting, and the fall in consumption between paydays. Discussion Paper No. 1430, http://www.iza.org/en/webcontent/publications/papers/viewAbstract?dp_id=1430

Ilinski, K. N., \& Stepanenko, A. S. (2008). Electro-dynamical model of quasi-efficient financial market. http://arxiv.org/pdf/cond-mat/9806138.pdf

Ivkovich, Z., J. Poterba \& Weisbenner, S. (2005). Tax-motivated trading by individual investors. The American Economic Review, 95(5), 1605-1630.

Iyer, S. B., \& Bhaskar, R. K. (2002). Investors' psychology: A study of investor behavior in the Indian capital market. Finance India, 16(4), 1357 - 1375.

Jensen,M. C. \& Meckling,W. H. (1976). Theory of the firm: Managerial behavior, agency costs and ownership structure, Journal of Financial Economics, 3(4), 305-360.

Jonesa, C. M., \& ,Lamon, O. A. (2002). Short-sale constraints and stock returns. Journal of Financial Economics, 66(2), 207-239.

Kaestner, M. (2005). Anomalous price behavior following earnings surprises: Does representativeness cause overreaction? Working Paper. GESEM, Universit'e Montpellier 1, CEROM Groupe, Sup de Co Montpellier, and CREGO, Universit'e Montpellier II. Source: http://128.118.178.162/eps/fin/papers/0505/0505018.pdf

Kahneman, D. (1980). Human engineering of decisions. In M. Kranzberg (Ed.), Ethics in an age of pervasive technology (190-192). Boulder, CO: Westview Press.

Kahneman, D., \& Tversky, A. (1974). Judgment under uncertainty: heuristics and biases. Science, 185 (4157), 1124-1131.

Kahneman, D., \& Tversky, A. (1979). Prospect theory: An analysis of decision under risk. Econometrica, 47(2), 263-292. 
Kahneman, D., \& Tversky, A. (1982). The psychology of preferences. Scientific American, 246(1), 160-73.

Kahneman, D., \& Tversky, A. (1984). Choices, values, and frames. The American Psychologist, 39(4), 341350

Kahneman, D., Knetsch, J.L., \& Thaler, R.H. (1990). Experimental tests of the endowment effect and the Coase-theorem. Journal of Political Economy, 98(6), 1325-1348.

Kathuria, L. M., \& Singhania, K. (2012). Investment decision making: A gender-based study of private sector bank employees. The IUP Journal of Behavioral Finance, 9(1), 45-56

Kaustia, M. (2010). Prospect theory and the disposition effect, Journal of Financial and Quantitative Analysis, 45(3), 791 - 812.

Keeler, J.P., James, W.L., Abdel-Ghany, M., 1985. The relative size of windfall income and the permanent income hypothesis. Journal of Business \& Economic Statistics, 3(3), 209-215.

Keijer, M. and H.M. Prast (2001), De telecom hype: hij was erecht (The telecom hype: it really existed), Economisch Statistische Berichten, 86(4302), 288-292

Keller, L. R., Sarin, R. K., \& Sounderpandian, J. (2007). An examination of ambiguity aversion: Are two heads better than one? Judgment and Decision Making, 2(5), 390-397

Kelly, M. (1997). Do noise traders influence stock prices? Journal of Money, Credit and Banking, 29(3), 351-363

Keynes, J. M. (1936). The General Theory of Employment, Interest and Money. London, Macmillan.

Kindleberger, P. C. \& Aliber, R. Z. 2005). Manias, panics, and crashes: A history of financial crises. Source: John Wiley \& Sons, Inc. http://www.nowandfutures.com/large/Manias,Panics,andCrashes.pdf

Kirabaeva, K. (2009). Can ambiguity aversion explain the equity home bias? http://web.stanford.edu/group/SITE/archive/SITE_2009/segment_8/segment_8_papers/kirabaeva.pdf.

Klein, A. C. (2012). Time-variations in herding behavior: Evidence from a Markov Switching Sur Model (July 5, 2012). Available at SSRN: http://ssrn.com/abstract=2000324 or http://dx.doi.org/10.2139/ssrn.2000324

Kogan, L., Ross, S. A., Wang, J., \& Westerfield, M.M. (2006). The price impact and survival of irrational traders. The Journal of Finance. 61(1), 195-229.

Koski, J. L., Rice, E. M., \& Tarhouni, A. (2004). Noise trading and volatility: Evidence from day trading and message boards. http://papers.ssrn.com/sol3/papers.cfm?abstract_id=533943

Kyle, A. S. (1985). Continuous auctions and insider trading. Econometrica, 53(6), 1315-1336.

Lakonishok, J., Shleifer, A., \& Vishny, R. (1994). Contrarian investment, extrapolation, and risk. The Journal of Finance. December, 49(4), 1541-1578.

Lee, C. M.C. (2001). Market efficiency and accounting research: A discussion of 'capital market research in accounting' by S.P. Kothari. Journal of Accounting and Economics, 31(1-3), 233-253.

Li, J. \& Yu, J. (2009). Psychological anchors, underreaction, overreaction, and asset prices. http://www.carlsonmba.umn.edu/assets/153169.pdf

Li, Y. \& Yang, L. (2013). Prospect theory, the disposition effect, and asset prices. Journal of Financial Economics, 107(3), 715-739

Lin, W. T., Tsai, S. C., Lung, P. Y. (2013). Investors' herd behavior: Rational or irrational? Asia-Pacific Journal of Financial Studies, 42(5), 755-776,

Liu, J., \& Longstaff, F. (2004). Losing money on arbitrages: Optimal dynamic portfolio choice in markets with arbitrage opportunities. Review of Financial Studies, 17(3), 611-641.

Ljungqvist, A. \& Qian, W. (2014). How constraining are limits to arbitrage? Evidence from a recent financial innovation. Working Paper. Available at: http://ssrn.com/abstract=2356414

Lo, A.W. \& MacKinlay, A. C. (1999). A Non-Random Walk Down Wall Street. Princeton: Princeton University Press.

Lo, A.W., Mamaysky, H. \& Wang, J. (2000). Foundations of technical analysis: Computational algorithms, statistical inference, and empirical implementation. The Journal of Finance. 55(4), 1705-765.

Long, J. (1978), The market valuation of cash dividends, Journal of Financial Economics, 6(2-3), 235-264.

Lord, C., Ross, L., \& Lepper, M. (1979). Biased assimilation and attitude polarization: the effects of prior theories on subsequently considered evidence. Journal of Personality and Social Psychology, 37(11), 2098-2109.

Malkiel, B. (2003). The efficient market hypothesis and its critics. Journal of Economic Perspectives, 17(1), 59-82. 
Mankiw, N. \& Zeldes, S. (1991). The consumption of stockholders and non-stockholders. Journal of Financial Economics, 29(1) 97-112.

Mayraz, G. (2013). Wishful thinking. Research Paper Number 1172, Department of Economics, the University of Melbourne. http://fbe.unimelb.edu.au/_data/assets/pdf_file/0008/796967/1172.pdf

Mehra, R., \& Prescott, E. (1985). The equity premium: A puzzle, Journal of Monetary Economics, 15(2), 145-161.

Merton, R. (1987). A simple model of capital market equilibrium with incomplete information. The Journal of Finance, 42(3), 483-510.

Milkman, K. L., \& Beshears, J. (2008). Mental accounting and small windfalls: Evidence from an online grocer, Working Paper No. 08-024; Source: http://www.hbs.edu/research/pdf/08-024.pdf

Miller, M., \& Scholes, M. (1982). Dividends and taxes: Some empirical evidence, Journal of Political Economy, 90(6), 1118-1141

Miller, M. H. (1986). Behavioral rationality in finance: The case of dividends. The Journal of Business, 59(4), S451-S468.

Moradi, M., Meshki, M., \& Mostafaei, Z. (2013). A study on investors' personality characteristics and behavioral biases: Conservatism bias and availability bias in the Tehran Stock Exchange. Management Science Letters, 3(4), 1191-1196

Mukerji, S. (1998). Ambiguity aversion and incompleteness of contractual form. The American Economics Review, 88(5), 1207-1231.

Mukerji, S., \& Tallon, J. (2001). Ambiguity aversion and incompleteness of financial markets, Review of Economic Studies, 68(4), 883-904.

Fama, E. (1970). Efficient capital markets: A review of theory and empirical work. The Journal of Finance, 25(2), $383-417$.

Northcraft, G., \& Neale, M. (1987). Experts, amateurs, and real estate: An anchoring and adjustment perspective on property pricing decisions, Organizational Behavior and Human Decision Processes, 39(1), 84-97.

Odean, T. (1998a). Volume, volatility, price and profit when all traders are above average, Journal of Finance, 53(6), 1887-1934

Odean, T. (1998b). Are investors reluctant to realize their losses? The Journal of Finance, 53(5), 17751798.

Odean, T. (1999). Do investors trade too much? The American Economic Review, 89(5), 1279 - 1298.

Podolski, E. B., Kaleva, P. S., \& Duongb, H. N. (2009). Deafened by noise: Do noise traders affect volatility and returns? http://www.melbournecentre.com.au/Finsia_MCFS/2009/Papers\%20for\%20website/40_Petko_Noise \%20traders.pdf.

Pontiff, J. (2006). Costly arbitrage and the myth of idiosyncratic risk. Journal of Accounting and Economics, 42(1), 35-52.

Poterba, J. \& Summers, L. (1988). Mean reversion in stock returns: Evidence and implications. Journal of Financial Economics, 22(1), 27-59.

Prasad, H. \& Mohta, B. (2012). Are professional and individual investors equally prone to disposition effect? Evidence from Indian stock market. http://www.greatlakes.edu.in/pdf/Herald/Vol6/sep2012_v6_c5.pdf.

Prosad, J. M., Kapoor, S., \& Sengupta, J. (2012). An examination of herd behavior: An empirical evidence from Indian equity market. International Journal of Trade, Economics and Finance, 3(2), (154 -157).

Raberto, M. Scalas, E., \& Mainardi' F. (2002). Waiting-times and returns in high-frequency financial data: An empirical study. Physica A: Statistical Mechanics and its Applications, 314(1-4), 749-755

Radalj, K., \&McAleer, M. (2003). Herding, information cascades and volatility spillovers in futures markets. http://bschool.nus.edu/departments/financenaccounting/seminars/papers/kim\%20radalj.pdf

Read, D., Loewenstein, G., \& Rabin, M. (1999). Choice bracketing. Journal of Risk and Uncertainty. 19(13), 171-197.

Ross, S. A. (1976). The arbitrage theory of capital asset pricing. Journal of Economic Theory, 13(3), 341360

Sahni1, D (2012). Behavioral finance: Testing applicability on Indian investors. International Journal of in Multidisciplinary and Academic Research, 1(2), 1 - 12. 
Sarin, R. K. \& Weber, M. (1993). Effects of ambiguity in market experiments. Management Science, 39(5), 602-615.

Savage, L. J. (1954). The Foundations of Statistics. John Wiley \& Sons Inc., New York.

Scheinkman, J., \& Xiong, W. (2003). Hetrogeneous beliefs, speculation and trading in financial markets. In Price - Princeton Lectures on Mathematical Finance. Eds, Bjork, T., Rutkowski, M., \&Xiong, W. $215-250$.

Schmidt, U., \&Zank, H. (2008). Risk aversion in cumulative prospect theory, Management Science, 54(1), 208-216.

Scruggs, J. T. (2007). Noise trader risk: Evidence from the Siamese twins, Journal of Financial Markets, 10(1), $76-105$.

Seiler, V. L., \& Lane, M. (2010). Mental accounting and false reference points in real estate investment decision-making, Journal of Behavioral Finance, 13(1), 17-26.

Shapira, Z., \& Venezia, I (2001). Patterns of behavior of professionally managed and independent investors, Journal of Banking and Finance, 25(8), 1573-1587.

Sharpe, W. F. (1964). Capital asset prices: A theory of market equilibrium under conditions of risk. The Journal of Finance, 19(3), 425-442.

Sharpe, W., \& Alexander, G. (1990). Investments, 4th edition, Englewood, NJ: Prentice Hall.

Shefrin, H. (2000). Beyond Greed and Fear: Understanding Behavioral Finance and the Psychology of Investing. Boston, MA: Harvard Business School Press.

Shefrin, H. (2002a). Beyond Greed and Fear: Understanding Behavioral Finance and the Psychology of Investing, Oxford University Press, Oxford.

Shefrin, H. (2002b). Behavioral decision making, forecasting, game theory, and role-play. International Journal of Forecasting, 18(3) 375-382.

Shefrin, H. (2007). Behavioral Corporate Finance. McGraw Hill, New York.

Shefrin, H., \& Statman, M. (1985). The disposition to sell winners too early and ride losers too long: Theory and evidence, The Journal of Finance 40(3), 777-790.

Shiha, T. L., Hsub, A. C., Yangc, S. J., \& Lee, C. C. (2012). Empirical research of herding behavior in the Pacific Basin stock markets: Evidence from the U.S. stock market rise (drop) in succession. The 2012 International Conference on Asia Pacific Business Innovation \& Technology Management. Procedia Social and Behavioral Sciences 00 (2012) 000-000.

Shiller, R., (1984). Stock prices and social dynamics. Brookings Papers on Economic Activity, 15(2), 457498.

Shleifer, A., \& Vishny, R. W. (1997). The limits of arbitrage. The Journal of Finance, 52(1), 35 - 55.

Sias, R. W., Starks, L. T., \& Tinic, S. M. (2001). Is noise trader risk priced? The Journal of Financial Research. 24(3). $311-329$.

Siegel, J. J. \&Thaler, R. H. (1997). Anomalies: The equity premium puzzle. Journal of Economic Perspectives, 11(1) 191 - 200.

Smith, L. and Soerensen, P. (2000). Pathological outcomes of observational learning. Econometrica. 68(2) 371-398.

So, E. C. \& Wang, S. (2011). Systematic noise and news-driven return reversals. http://areas.kenanflagler.unc.edu/Accounting/fallcamp/Document\%20Library/Systemic\%20Noise\%20and\%20NewsDriven\%20Return\%20Reversals_Wang.pdf.

Statman, M. (1999). Behavioral finance: Past battles and future engagements. Financial Analysts Journal, 55(6), 18-27.

Statman, M. (2008). What is behavioral finance? John Wiley \& Sons, Inc. in Handbook of Finance, vol. II, chapter 9, ed. Frank J. Fabozzi (Hoboken, NJ: John Wiley \& Sons, Inc.): 79-84.

Stracca, L. (2002). The optimal allocation of risks under prospect theory, Working Paper No. 161, the European Central Bank Working Paper Series, https://www.ecb.europa.eu/pub/pdf/scpwps/ecbwp161.pdf.

Strobl, G. (2003). Information asymmetry, price momentum, and the disposition effect. Job Market Paper, $\mathrm{ftp} / / / \mathrm{ftp} . c e m f i . e s / p d f /$ papers/wshop/dispeff.pdf.

Subash, R. (2012). Role of behavioral finance in portfolio investment decisions: Evidence from India, http://ies.fsv.cuni.cz/default/file/download/id/20803 
Tesar, L. \& Werner, I. (1995). Home bias and high turnover. Journal of International Money and Finance 14(4), $467-792$

Thaler, R. (1980). Toward a positive theory of consumer choice. Journal of Economic Behavior and Organization, 1 (1), 39-60.

Thaler, R. (1999). Mental accounting matters. Journal of Behavioral Decision Making, 12(3), 183-206.

Thaler, R. H. (1983). Transaction utility theory in advances in consumer research, Volume 10, eds. Richard P. Bagozzi and Alice M. Tybout, Ann Abor, MI: Association for consumer research, Pages: 229-232.

Thaler, R. H. (1985). Mental accounting and consumer choice, Marketing Science, 4(3), 199-214.

Thaler, R., \&Shefrin, H. (1981). An economic theory of self-control, Journal of Political Economy, 89(2), 392-410.

Thaler, R., and Barberis, N., (2002). A Survey of Behavioral Finance, Handbook of the Economics of Finance, National Bureau of Economic Research. http://faculty.som.yale.edu/nicholasbarberis/ch18_6.pdf.

Thaler, R.H. (2008). Mental accounting and consumer choice, Marketing Science, 27(1), 15-25.

Tuckman, B., \& Vila, J.-L. (1992). Arbitrage with holding costs: A utility based approach. The Journal of Finance, 47(4), 1283-1302.

Tversky, A. \& Kahneman, D. (1991). Loss aversion in riskless choice: A reference dependent model. Quarterly Journal of Economics, 107(4), 1039-1061.

Tversky, A. \& Kahneman, D. (1992). Advances in prospect theory: Cumulative representation of uncertainty. Journal of Risk and Uncertainty, 5(4), 297-323.

Tversky, A., \& Kahneman, D. (1981). The framing of decisions and the psychology of choice. Science, 211(4481), 453-458.

Tversky, A., \& Kahneman, D. (1986). Rational choice and the framing of decisions. Journal of Business, 59(4), S251-S278.

Veronesi, P. (1999). Stock market overreaction to bad news in good times: A rational expectation equilibrium model. The Review of Financial Studies, 12(5), 975 - 1007.

Von Neumann, J., \& Morgenstern, O. (1944). Theory of Games and Economic Behavior, Princeton: Princeton University Press, http://press.princeton.edu/titles/7802.html.

Wakker, P. P. (2010). Prospect Theory for Risk and Ambiguity. Cambridge University Press, Cambridge, UK. http://people.few.eur.nl/wakker/oldpsabs.htm\#abs10.3

Wang, H., Yan, J., \& and Yu, J. (2014). Reference-dependent preferences and the risk-return trade-off. Source: http://users.cla.umn.edu/ jianfeng/Reference_MV.pdf

Weber, M. \& Camererb, C. F. (1998). The disposition effect in securities trading: an experimental analysis. Journal of Economic Behavior\& Organization, 33(2), 167-184

Weinstein, N. D. (1980). Unrealistic optimism about future life events. Journal of Personality and Social Psychology, 39(5), 806-820

Wu, G., \& Markle, A. B. (2007). An empirical test of gain-loss separability in prospect theory. Management Science, forthcoming http://www.chicagocdr.org/cdrpubs/pdf_index/cdr_571.pdf

Wu, G., Zhang, J., \& Abdellaoui, M. (2005). Testing prospect theories using probability tradeoff consistency. Journal of Risk and Uncertainty, 30(2), 107-131.

Zhang, J., \& Liu, P., (2012). Rational herding in microloan markets. Management Science, 58(5), 892-912.

Zouaoui, M., Nouyrigat, G., \& Beer, F. (2011). How does investor sentiment affect stock market crises? Evidence from panel data. The Financial Review, 46(4), 723-747. 